\title{
A Study on Resilience Improvement Program for School Violence Prevention
}

\author{
Young-Hee Lee ${ }^{1}$, Mi-Na Lee ${ }^{2}$ \\ ${ }^{1}$ Outpatient Professor, Department of Social Welfare, Honam Theological University, South \\ Korea,lea0315@hanmail.net \\ ${ }^{2}$ Professor, Welfare Counseling Convergence Department, Kwangshin University, South Korea, \\ Imn4780@naver.com
}

Corresponding author: $\mathrm{Mi}$-Na Lee

\begin{abstract}
This paper is a basic study on the resilience improvement program for the prevention of school violence. To this end, adolescents' school violence status was investigated together with problems of protection factors and risk factors, and improvement measures which were identified to explore the applicability of the resilience improvement program for the prevention of school violence. The survey was conducted to 1,599 adolescents located in J-gun, Jeollanam-do from August to November, 2020. Data analysis was performed using SPSS WIN 21.0. The research results are as follows. First, it was found that studies related to programs for school violence victims are continuously increasing, and research topics are varied in accordance with social movements. Second, when looking at the existing programs for victims of school violence, the contents of programs related to the improvement of resilience were found to be insufficient. In addition to the school violence prevention program, the study suggests the necessity of developing a school violence prevention program to improve resilience in order to cultivate the strength to overcome by oneself in order to grow healthy during adolescence. Therefore, this study is intended to present a method of mutual sympathy for psychological pain and a healthy communication method by training to improve resilience to prevent school violence.
\end{abstract}

Keywords: School Violence Prevention, Risk Factors, Protective Factors, Resilience, Crisis Youth

\section{Introduction}

Human socialization experiences occur in interaction with parents and other family members. But as they grow up, they interact with their peers and experience new socialization. Adolescents spend most of their time in school. Adolescence develops positive self-concept and self-respect by learning socialization skills, developing social skills, and gaining psychological stability and support through peer interaction in the space of school[1]. As such, the school is a place that promotes comprehensive development of academic adaptation, career, and social skills by promoting the well-being and happiness of students. In it, a sense of community creates trust, consideration, respect, emotional intimacy, cooperation and care between school adaptation and members to experience a sense of well-being and well-being by fulfilling one' strengths and potential[2].

However, school currently evaluate their academic performance, causing competition among students and classes, and establishing hierarchies through competition, checks, quarrels, and violence, not cooperation. In other words, the experience of school violence damage caused by peer conflict has

Received: April 27, 2021; $1^{\text {st }}$ Review Result: June 10, 2021; $2^{\text {nd }}$ Review Result: July 27, 2021

Accepted: August 30, 2021 
emerged as a serious social problem. This seriousness is distinctly different from the past, with school violence cases being dealt with through the media. Our society strives on an educational and social level to eradicate violent crime. But despite these efforts, school violence is increasing and getting bolder as it spreads in various form[3].

Peer relationships cannot always be stable. Even if they are in conflict with peers, they should acquire skills to effectively resolve conflict problems with appropriate interactions. This allows them to form more positive and mature self-concept, thus, creating a smooth peer relationship. However, negative experiences in peer relationships are a problem, such as conflicts that cause friction if rejected or not recognized. Failure to resolve the conflict in a reasonable way can result in negative self-concept, which can lead to difficulties in school maladjustment and further lead to social maladjustment in adulthood[4]. This maladaptation leads to peer-related friction and, in turn, peer-to-peer violence, wounding by physical and mental distress, which has a significant impact on life not only during adolescence but also in adulthood[3].

The Act on the Prevention and Countermeasures of School Violence (Amendment No. 11223 of the Act) enacted in 2004 takes into account social changes and uses school violence as "injury, assault, confinement, intimidation, coercion, sexual violence, cyberbullying, information and communication networks." Even behavior that began as a "minor prank" inside and outside the school can be identified as school violence if it causes physical harassment and mental injury to friends. Under the law, the definition of school violence includes a place where school violence takes place "in and out of school," a subject of school violence called "violators and victims" and a category of school violence of "physical, mental or property damage."

In addition to the legal definition of school violence, academic research on school violence is conducted, raising questions related to the definition of school violence in terms of academic aspects. School violence has been defined slightly differently depending on the location of violence, the type of violence, the subject of violence, and the persistence of violence. It can depend on whether the violence is limited to schools, including violence experienced around schools and on the way to and from school, or violence against teachers and school administrators as well as between students. The damage from school violence remains an aftereffect and has a difficulty in forming smooth interpersonal relationships with others, which negatively affects identity confusion and overall personality and behavior. Studies show that these psychological aftereffects are also highly related to suicide[5]. Studies of college students who experienced school violence during adolescence showed that they experience more anxiety, depression, and social anxiety than college students who did not experience school violence. This also affects stable adult attachment formation[5].

Adolescence is a time when positive thinking is needed because self-identity is formed due to the characteristics of development and is greatly influenced by peer relationships. Resilience refers to the ability of humans to overcome difficult situations or problems and grow as they adapt to the environment. Adolescence leads to difficulties in physical, mental, and emotional functioning, and the exit to relieve their pain becomes limitedly vulnerable to stress[6]. Exposure to multiple stress situations and risks causes psychological and behavioral problems, but some grow up normally, adapting well to the situation and maintaining a stable state of mind. The latter students are resilient students who overcome the hardships that have come to them and are more likely to grow and improve[7]. This resilience aims to help adolescents themselves relieve stress and overcome difficulties on their own[7]. It also helps to accurately identify one's difficult situation even in stressful situations and to try to find broader and more reasonable observations and solutions to the problem. This is to take self-control over one's life and try to control one's negative behavior, and to find new solutions by utilizing social connections with oneself, such as family and peers[8]. For this development of resilience, it is necessary to induce substantial changes in individual inner self of adolescents to lead to changes in behavior, suggesting that the introduction of programs for resilience is very important. 
Related studies of resilience include improving self-control[9], poor learning[10], and problem solving[11] through emotion control. The resilience program develops one's positive strengths to improve one's inner emotions in order to have a healthier and happier state of self-realization. Therefore, research on resilience programs is necessary for youth victims of school violence. However, few studies were conducted to improve the resilience of school violence victims.

Therefore, this study is aimed to improve school violence prevention and resilience by exploring risk factors and protective factors of youth victims of school violence. Furthermore, it seeks to answer the following research questions. First, what are the risk factors for adolescents? Second, what is the composition and content of the program to promote resilience to prevent school violence?

\section{Recovery Elasticity Enhancement Program}

\subsection{Contents of the Recovery Elasticity Improvement Program}

The Restorative Elasticity Program for the Prevention of School Violence is a program to promote the hope of a happy life by improving motivation for active participation in order to achieve the goal of improving emotional empathy and resilience This study aims to improve resilience to prevent school violence[12], to reconstruct resilience[13], to improve self-esteem[14], and to enhance positive emotions and representative strength-related treatment effects[15]. he criteria for restructuring are as follows: First, with happiness, which is an area based on positive psychology, it is organized to have experiences based on the goals of early, medium, and end stages, focusing on pleasant life, active life, and meaningful life. Second, due to the characteristics of adolescents, activities per session consisted of 60 minutes, and introduced, developed, and finished. Third, considering the preference for physical activities over static activities due to the characteristics of adolescents, the program included physical activities and activities for emotional relaxation that could increase intimacy between counselors and target students. Fourth, the concept of forgiveness in positive psychology can be abstract for teenagers to understand, allowing them to use concrete examples and pictures to help them with the concept of forgiveness. Fifth, the development process created an atmosphere for people to participate comfortably by turning on meditation music, and organized them into two to three topics, allowing them to share their stories and experiences without any burden. Sixth, emphasizing that art is not good or bad, expression media were used to help relieve tension and express emotions, and to experience individual positive emotions and resilience through creative self-expression, inner self-awareness, free language, and nonverbal message expression.

\subsection{Contents of the Recovery Elasticity Enhancement Program}

The contents of the recovery elasticity promotion program are as shown as [Table 1].

[Table 1] Recovery Elasticity Enhancement Program

\begin{tabular}{|c|c|c|c|c|}
\hline Step & Session & Subject & Goal & Activity Contents \\
\hline \multirow{3}{*}{$\begin{array}{l}\text { Pleasant } \\
\text { life }\end{array}$} & 1 & $\begin{array}{l}\text { Let me introduce } \\
\text { myself. }\end{array}$ & $\begin{array}{l}\text { Forming intimate } \\
\text { relationships } \\
\text { Self-exposure }\end{array}$ & $\begin{array}{l}\text { Making an appointment } \\
\text { Introduce yourself and build rapport }\end{array}$ \\
\hline & 2 & manner & $\begin{array}{c}\text { a social nature } \\
\text { Consideration and } \\
\text { empathy }\end{array}$ & $\begin{array}{l}\text { Relational Formation by Color Division } \\
\text { Resolving conflicts and promoting mutual relationships }\end{array}$ \\
\hline & 3 & Emotion open & $\begin{array}{l}\text { Positive Self- } \\
\text { Awareness } \\
\text { Creativity }\end{array}$ & $\begin{array}{l}\text { Feelings only } \\
\text { Expressing Emotions with Colour Salt }\end{array}$ \\
\hline
\end{tabular}




\begin{tabular}{|c|c|c|c|c|}
\hline & 4 & precious family & $\begin{array}{l}\text { thanks } \\
\text { Creativity }\end{array}$ & $\begin{array}{c}\text { Organizing Familyization } \\
\text { Express colors, shapes associated with an image } \\
\text { an active life }\end{array}$ \\
\hline \multirow{4}{*}{$\begin{array}{l}\text { An active } \\
\text { life }\end{array}$} & 5 & $\begin{array}{l}\text { My strength } \\
\text { resources }\end{array}$ & $\begin{array}{l}\text { Self-esteem } \\
\text { Self-awareness }\end{array}$ & $\begin{array}{l}\text { Knowing the strengths of personality } \\
\text { Sharing immersion experiences }\end{array}$ \\
\hline & 6 & A happy smile & $\begin{array}{l}\text { Optimism } \\
\text { thanks }\end{array}$ & $\begin{array}{l}\text { Practicing in life with happiness and a smile. } \\
\text { Expressing happiness with body and clay }\end{array}$ \\
\hline & 7 & $\begin{array}{l}\text { the weight of one's } \\
\text { emotions }\end{array}$ & $\begin{array}{l}\text { Self-awareness } \\
\text { integrity, patience }\end{array}$ & $\begin{array}{l}\text { Self-recognition through the body - plaster bandages. } \\
\text { Looking into suppressed emotions }\end{array}$ \\
\hline & 8 & peace of mind & $\begin{array}{l}\text { Forgiveness } \\
\text { courage }\end{array}$ & $\begin{array}{l}\text { Know the meaning of forgiveness } \\
\text { Throwing away all the hard work you've done. } \\
\text { Write and send a future letter in } 20 \text { years. } \\
\text { a meaningful life }\end{array}$ \\
\hline \multirow{4}{*}{$\begin{array}{l}\text { Meaningful } \\
\text { life }\end{array}$} & 9 & different minds & $\begin{array}{l}\text { prudence, } \\
\text { Openness }\end{array}$ & $\begin{array}{l}\text { I-massage, drawing in ear and knowing how others feel. } \\
\text { Understand me and understand others. } \\
\text { Changing roles and experiencing }\end{array}$ \\
\hline & 10 & A happy tree is & $\begin{array}{l}\text { thanks } \\
\text { Vitality }\end{array}$ & $\begin{array}{l}\text { Expressing Past, Present, and Future } \\
\text { The people who supported me, } \\
\text { Words of support and the magnitude of love. }\end{array}$ \\
\hline & 11 & Life panorama & $\begin{array}{c}\text { hope } \\
\text { Optimism }\end{array}$ & $\begin{array}{l}\text { Create an alias that is different from the current alias } \\
\text { Panorama of past, present, future life. }\end{array}$ \\
\hline & 12 & $\begin{array}{l}\text { A mask of } \\
\text { happiness }\end{array}$ & $\begin{array}{l}\text { self-optimism } \\
\text { courage, integrity }\end{array}$ & $\begin{array}{l}\text { Decorate your happiest face } \\
\text { Share how you feel about programs }\end{array}$ \\
\hline
\end{tabular}

As shown in [Table 1], the program was divided into a fun life, and a meaningful life, with a total of 12 programs planned.

The program progress for each session is as follows:

The first session introduces the program to improve resilience and introduces daily life as a measure of happiness. They also describe themselves with adjectives and introduce themselves to form intimacy. In the second session, they share words of encouragement and support to each other, reminiscent of images, and work on ritualization. It also forms empathy, control, and sociality to understand each other and achieve harmony through color. The third session uses emotion cards to recognize one's emotions, check the ratio of positive and negative emotions, and to cheer oneself up with positive words, conscious of emotions.

You can feel positive and beneficial emotions that convey energy to each other while thinking about each family member in the fourth session and experiencing a sense of community with love and gratitude for the family. In the fifth session, the emotions of the day will be examined through emotion cards and resilience activities will be carried out by introducing one thing each. They read the poem "I'm Great" and share how to raise self-awareness and self-esteem. In the sixth episode, they listen to the song "I'm so happy to have you" and change the lyrics, looking for people who they want to give the songs as gifts and share their feelings. While working with angel clay, he expresses his gratitude by helping smoothness and emotional relaxation. In the seventh session, they read the poem "Flower of Grass" and look at the phrases that touch their hearts and see that everything they want to share this poem with takes a long time. The optical illusion allows people to look at wounds from different perspectives and freely express unresolved wounds through role-playing and Bean's use of self-help.

In the eighth session, they can write future letters by practicing throwing away bad feelings using balloons and learning about true forgiveness through movies. The ninth session is the reenactment of conflict situation.

It changes each person's role and recognizes the importance of communication. Also, they express messages, practice, and talk to friends. In the 10th session, they learn what it takes for trees to grow through Happy Tree songs and express their gratitude to the people around them who created trees using 
their body and who sent them their body and who sent the Positive energy. In the 11th inning, they relieve tension and share their feelings with mirror sculpture games. By changing the negative words attached to them into positive words, it helps them have hope and expectation for life by creating a positive self-image that can change as they think. The 12th session divides happy times with colored chocolate to look back and express oneself in the happiest times and to recognize and accept the feelings of oneself and others.

\section{Research Method}

\subsection{Research Subjects}

In this study, the youth counseling and welfare center in J-gun, Jeollanam-do, identified the crisis level of teenagers in the region and analyzed it based on a survey on the actual situation of youths in crisis to develop and support effective counseling support programs. A total of 1,599 students were eligible, 815 comprised of boys (51\%) and 784 girls (49\%) and 432 elementary school students (27\%), 697 middle school students $(43,6 \%)$, and 470 high school students $(29.4 \%)$. The survey period was conducted from August to November 2020.

\subsection{Research Tools}

This research tool used a survey on youth crisis developed by the Korea Youth Counseling and Welfare Development Institute (2016)[16].

\subsubsection{Risk Factors}

In order to understand the status of youth crises, a measure of risk factors' crisis outcomes was prepared by referring to variable descriptions. A total of 38 questions on risk factors were used. The individual, home, school, and community areas of the subjects are divided into sub-factors for practical service provision. Individual areas are classified as depression, anxiety, aggression, impulsiveness and carelessness (16 questions), family areas as parents' conflicts, neglect, and problematic family members (11 questions), school areas as school life maladjustment (3 questions) and peer areas as delinquent friends (4 questions). The total number of questions is 38, and the inspection tool's response method used a five-point Likert scale that evaluates from "Not at all ( 0 point)" to "Very Yes (4 points)." The reliability coefficient of this study (Cronbach's $\alpha$ ) is the overall risk factor $\alpha=.91$, hypothesis (1) $\alpha=.83$, school $\alpha=.70$, assumption (2) $\alpha=.68$, community $\alpha=.81$, and peer $\alpha=.72$, among the protective factors. It turned out to be 85 . The hazard question configuration is the same as [Table 2].

[Table 2] Configuring Risk Factors Questions

\begin{tabular}{c|c|c|c|c}
\hline \multicolumn{2}{|c|}{} & \multicolumn{1}{c|}{ Topics } & Questions & Cronbach's $\alpha$ \\
\hline \multirow{5}{*}{ Risk factors } & Individual & $\begin{array}{c}\text { Depression, anxiety, aggression, impulsiveness, } \\
\text { carelessness }\end{array}$ & 16 & .91 \\
\cline { 2 - 5 } & Family & Conflict between parents, conflict with parents, neglect; & 8 & .83 \\
\cline { 2 - 5 } & School & Inadaptation to school life & 4 & .70 \\
\cline { 2 - 5 } & Community & Harmful community environment & 3 & .81 \\
\cline { 2 - 5 } & Family(2) & Problematic family members & 3 & .68 \\
\cline { 2 - 5 } & Peer & Juvenile delinquent & 3 & .72 \\
\cline { 2 - 5 } & total & & 38 & .85 \\
\hline
\end{tabular}




\subsubsection{Protective Factors}

As a sub-domain of protection factor measurement, individual areas were classified into self-respect, sense of goal, and active response (5 questions). Family areas were classified into family interests and trust ( 3 questions), peer areas into friend relationships ( 2 questions), school areas into teacher interests and relationships ( 2 questions), and community areas into support systems ( 3 questions). The total number of questions is 15 questions, and the inspection tool's response method used a five-point Likert scale that evaluates from "Not at all ( 0 point" to "Very Yes (4 points)." The reliability factor (Cronbach's $\alpha$ ) in this study is the overall protective factor $\alpha=.76$, the assumption $\alpha=.84$, the peer $=.78$, the school $\alpha=.80$, and the community $\alpha=.77$, which is the overall protective factor $\alpha=.76$.It turned out to be 86 . The protection factor question configuration is the same as [Table 3].

[Table 3] Configuring Protection Factor Questions

\begin{tabular}{c|c|c|c|c}
\hline \multicolumn{2}{c|}{} & Topics & Questions & Cronbach's $\alpha$ \\
\hline \multirow{4}{*}{$\begin{array}{c}\text { Protective } \\
\text { factors }\end{array}$} & Individual & Self-respect, awareness of goals, and active response; & 5 & .76 \\
\cline { 2 - 5 } & Home & Family interests and trust & 3 & .84 \\
\cline { 2 - 5 } & School & Friendly relationship & 2 & .78 \\
\cline { 2 - 5 } & Community & Teacher Interests and Relationships & 2 & .80 \\
\cline { 2 - 5 } & Total & Support system & 3 & .77 \\
\hline
\end{tabular}

\subsubsection{The Result of Crisis}

Among 57 elementary school students, 58 middle and high school students, 10 experiences of school violence and abuse, suspension of schoolwork, and maladjustment to school are used in this study. Each question is from on a five-point Likert scale, with "No at all ( 0 point), "No one (1 point), "No two (2 points), "No two times a week ( 3 points), "No almost every day (4 points)" or "No one (1 point)" or "No, "No two-3, "No two" or "No.

\subsection{Data Analysis}

The survey on the status of youth crisis in this study used the data collected by the Youth Counseli ng and Welfare Center in J-gun. Frequency analysis was conducted and used to identify the general characteristics of youth in $J$ group. As a result of implementation, protection factors, risk factors, and counseling recognition are confirmed and reliability of each factor is calculated. In addition, crossanalysis is used to verify differences between groups based on general characteristics: gender, school type, economic level, emotional support, and material support, and group-by-group mean analysis is conducted.

\section{Study Result}

\subsection{Research Subjects}

The demographic characteristics of the study subjects are as shown in [Table 4]. 
[Table 4] Characteristics of the Person Surveyed

\begin{tabular}{c|c|c|c}
\hline \multirow{2}{*}{ Sender } & Man & Frequency (in numbers) & Percentage (\%) \\
\hline \multirow{3}{*}{ Adolescent Type } & Woman & 815 & 51 \\
\cline { 2 - 4 } & elementary school student & 784 & 49 \\
\cline { 2 - 4 } & Middle school student & 432 & 44 \\
\cline { 2 - 4 } & High school student & 470 & 29 \\
\hline
\end{tabular}

According to the characteristics of the survey subjects as shown in [Table 4], there are 1,599 men (51\%), 784 women (49\%), 432 elementary school students (27\%), 697 middle school students (44\%), and 470 high school students (29\%).

\subsection{Risk Factors of the Study Subjects}

The average analysis of risk factors for the subjects in the study is shown in [Table 5].

[Table 5] Analysis of Risk Factor Means for Study Subjects (N=1599)

\begin{tabular}{c|c|c|c}
\hline Sortation & Subfactors & mean(M) & Standard Deviation (SD) \\
\hline \multirow{3}{*}{ Individual } & depression and anxiety & .81 & .79 \\
\cline { 2 - 4 } & Aggression, impulsiveness, carelessness & .72 & .62 \\
\hline \multirow{3}{*}{ Family } & Home parental conflict & .42 & .68 \\
\cline { 2 - 4 } & Conflicts and neglect between parents & .26 & .44 \\
\cline { 2 - 4 } & Problematic family members & .03 & .10 \\
\hline Peer & juvenile delinquent & .04 & .14 \\
\hline School & Inadaptation to school life & .57 & .51 \\
\hline Community & Harmful community environment & .29 & .67 \\
\hline
\end{tabular}

As shown in [Table 5], the analysis of the average risk factors of the study showed that the "depression and anxiety" mean was the highest $(\mathrm{M}=.81)$, " followed by aggression and impulsiveness" $(\mathrm{M}=.72)$, "non-school life adaptation" ( $\mathrm{M}=.57)$, "community conflict" ( $\mathrm{M}=.29)$, and "flying conflict and neglect" $(\mathrm{M}=6.2)$.

\subsection{Protective Factors of the Study Subjects}

The average analysis of the protection factors of those studied is as shown in [Table 6].

[Table 6] Analysis of the Mean of Protection Factors for the Subjects $(\mathrm{N}=1599)$

\begin{tabular}{c|c|c|c}
\hline Sortation & Subfactors & mean(M) & Standard DeviationSD) \\
\hline \multirow{3}{*}{ Individual } & Self-respect & 2.91 & .79 \\
\cline { 2 - 4 } & Sense of goal & 3.12 & 1.00 \\
\cline { 2 - 4 } & Aggressive response & 3.04 & .94 \\
\hline \multirow{2}{*}{ Family } & Family interests and trust & 3.26 & .77 \\
\hline Peer & Friendly relationship & 3.28 & .86 \\
\hline
\end{tabular}




\begin{tabular}{c|c|c|c}
\hline School & Teacher Interests and Relationships & 2.79 & .96 \\
\hline Community & Support system & 2.44 & 1.08 \\
\hline
\end{tabular}

As shown in [Table 6], the average analysis of protective factors in the study showed that "friend relationships" were the highest( $\mathrm{M}=3.28)$, followed by "family interest and trust" $(\mathrm{M}=3.26)$, "target awareness" ( $\mathrm{M}=3.12)$, "active response" $(\mathrm{M}=3.91)$, "teacher interest and relationship" $(\mathrm{M}=2.79)$,

\subsection{Crisis Results of Subjects in the Study}

The average analysis of the crisis results of the subjects in the study is as shown in [Table 7].

[Table 7] Analysis of the Mean of Crisis Results of Study Subjects

\begin{tabular}{c|c|c|c}
\hline Sortation & N & mean(M) & Standard deviation(SD) \\
\hline School Violence (Damage) & 1599 & 0.07 & 0.25 \\
\hline $\begin{array}{c}\text { School violence (abuse) } \\
\begin{array}{c}\text { Discontinuation of school and maladaptation to } \\
\text { school }\end{array}\end{array}$ & 1599 & 0.06 & 0.20 \\
\hline
\end{tabular}

The average analysis results of the crisis results of those studied were "school violence (damage) $(\mathrm{M}=.07)$, "school violence (violation)" (M=.06), and "school suspension and school maladjustment $(\mathrm{M}=.02)$.

\subsection{Average Analysis of Crisis Results by School Type}

The average analysis results of crisis results by school type are as shown in [Table 8].

[Table 8] Analysis Results of Crisis Results by School Type

\begin{tabular}{|c|c|c|c|c|c|c|}
\hline Crisis Area & School Type & $\begin{array}{c}\text { Frequency (in } \\
\text { numbers) }\end{array}$ & Average & $\begin{array}{r}\text { Standard } \\
\text { deviation }\end{array}$ & $\mathrm{F}$ & Scheffe \\
\hline \multirow{4}{*}{$\begin{array}{l}\text { School Violence - } \\
\text { Damage }\end{array}$} & elementary & 432 & 0.110 & 0.308 & \multirow{4}{*}{$8.482 * * *$} & \multirow{4}{*}{ Middle $\cdot$ high $<$ elementary } \\
\hline & middle school & 697 & 0.055 & 0.232 & & \\
\hline & high school & 470 & 0.048 & 0.219 & & \\
\hline & sum & 1599 & 0.067 & 0.216 & & \\
\hline \multirow{4}{*}{$\begin{array}{c}\text { School Violence - } \\
\text { Violation }\end{array}$} & elementary & 432 & 0.084 & 0.272 & \multirow{4}{*}{$6.355^{* * *}$} & \multirow{4}{*}{ Middle $\cdot$ high $<$ elementary } \\
\hline & middle school & 697 & 0.012 & 0.185 & & \\
\hline & high school & 470 & 0.009 & 0.135 & & \\
\hline & sum & 1599 & 0.012 & 0.201 & & \\
\hline \multirow{4}{*}{$\begin{array}{l}\text { Discontinuation } \\
\text { of school and } \\
\text { maladaptation to } \\
\text { school }\end{array}$} & elementary & 432 & 0.019 & 0.111 & \multirow{4}{*}{$1.141^{*}$} & \multirow{4}{*}{ Middle $\cdot h i g h$ elementary } \\
\hline & middle school & 697 & 0.019 & 0.164 & & \\
\hline & high school & 470 & 0.032 & 0.191 & & \\
\hline & sum & 1599 & 0.025 & 0.161 & & \\
\hline \multirow{4}{*}{$\begin{array}{l}\text { Overall Crisis } \\
\text { Outcomes }\end{array}$} & elementary & 432 & 0.124 & 0.157 & \multirow{4}{*}{$3.131 * *$} & \multirow{4}{*}{$\begin{array}{l}\text { Middle·high } \\
\text { elementary }\end{array}$} \\
\hline & middel school & 697 & 0.137 & 0.156 & & \\
\hline & high school & 470 & 0.115 & 0.133 & & \\
\hline & sum & 1599 & 0.127 & 0.149 & & \\
\hline
\end{tabular}

$* \mathrm{p}<.05, * * \mathrm{p}<.01, * * * \mathrm{p}<.001$ 
As shown in [Table 8], school violence (damage and abuse) was the highest average for elementary school students. As a result of the crisis, the average of middle school students was the highest, and the average difference between youth types was also statistically significant at a significance level of 5\%.

\subsection{Correlation between Risk Factors and Crisis Outcomes}

The correlation between risk factors and crisis outcomes is as shown in [Table 9].

[Table 9] Correlation between Risk Factors and Crisis Outcomes

\begin{tabular}{|c|c|c|c|c|c|c|c|c|}
\hline Risk factors & $\begin{array}{l}\text { Depression } \\
\text { and anxiety }\end{array}$ & $\begin{array}{l}\text { Aggression, } \\
\text { impulsiveness, } \\
\text { carelessness }\end{array}$ & $\begin{array}{l}\text { Conflicts } \\
\text { with parents } \\
\text { and neglect; }\end{array}$ & $\begin{array}{l}\text { Parental } \\
\text { conflict }\end{array}$ & $\begin{array}{l}\text { Problematic } \\
\text { Family } \\
\text { Member }\end{array}$ & $\begin{array}{l}\text { Problem of } \\
\text { School life }\end{array}$ & $\begin{array}{l}\text { Community } \\
\text { Harmful } \\
\text { Meniscope }\end{array}$ & $\begin{array}{c}\text { Juvenile } \\
\text { delinquent }\end{array}$ \\
\hline $\begin{array}{l}\text { School Violence - } \\
\text { Damage }\end{array}$ & $.176^{* *}$ & $.122 * *$ & $.110^{* *}$ & $.145^{* *}$ & $.090 * *$ & $.102 * *$ & $.087 * *$ & $.087 * *$ \\
\hline $\begin{array}{l}\text { School Violence - } \\
\text { Violation }\end{array}$ & $.104^{* *}$ & $.255^{* *}$ & $.103^{* *}$ & $.113^{* *}$ & $.104^{* *}$ & $.101^{* *}$ & $.135^{* *}$ & $.145^{* *}$ \\
\hline $\begin{array}{l}\text { Discontinuation of } \\
\text { study and non- } \\
\text { adaptation to } \\
\text { school }\end{array}$ & $.173^{* *}$ & $.190 * *$ & $.222 * *$ & $.113^{* *}$ & $.090 * *$ & $.187 * *$ & $.087 * *$ & $.221 * *$ \\
\hline
\end{tabular}

As shown in [Table 9], the correlation between the overall crisis outcome and risk factors showed a statistically significant positive correlation at a significance level of $5 \%$, mostly low (over 0.06 ). Those less than three showed correlation. Factors that are more correlated than other factors showed a static correlation with suicide $(\mathrm{r}=.515)$ and self-injury $(\mathrm{r}=409)$ in depression and anxiety, and suicide $(\mathrm{r}=.238)$ and self-injury ( $\mathrm{r}=.296)$. Overall, the biggest risk factors related to the crisis are depression and anxiety factors.

\subsection{Correlation between Protective Factors and Crisis Outcomes}

The correlation between protection factors and crisis outcomes is as shown in [Table 10].

[Table 10] Correlation between Protection Factors and Crisis Outcomes

\begin{tabular}{|c|c|c|c|c|c|}
\hline $\begin{array}{ll}\text { Crisis Result } & \text { Risk factors } \\
\end{array}$ & Individual & Family & Peer & School & Community \\
\hline School Violence - Damage & $-.067 * *$ & $-.059 *$ & $-.122 * *$ & $-.051 *$ & $-.072 * *$ \\
\hline School Violence - Violation & $-.084 * *$ & $-.063 *$ & $-.065 * *$ & $-.085^{* *}$ & $-.090 * *$ \\
\hline $\begin{array}{l}\text { Discontinuation of study and } \\
\text { non-adaptation to school }\end{array}$ & $-.104 * *$ & $-.111 * *$ & $-.079 * *$ & $-.098 * *$ & $-.107^{* *}$ \\
\hline
\end{tabular}

As shown in [Table 10], the correlation between overall crisis outcomes and protective factors was statistically significant at a significance level of five percent, mostly weak (over 0.05). Those less than two) showed a negative correlation. The relatively high negative correlation with each protective factor shows that school violence-violence $(\mathrm{r}=-.064)$ is an inadequate correlation in individuals (self-esteem, sense of goal, and active response). Overall, the biggest protection factor associated with crisis outcomes 
is individual and family factors, and family interest and trust.

\section{Conclusion}

This study was based on the results of a survey on the crisis situation of teenagers using the crisis survey questions developed by the Korea Youth Counseling and Welfare Development Institute (2016). The questions consisted of risk factors (38) and protection factors (15), crisis outcomes (44) and demographic fundamental.

First, the subjects of the study were teenagers attending elementary, middle and high schools in J-gun, and 2,000 elementary and high school students from 5th grade or higher to 2 nd grade participated. The questionnaires for 434 elementary school students and 1,165 middle and high school students were finally analyzed and used, except for unfaithful responses. In the survey, 51\% (815) were men and 49\% (784 students) were women. In terms of youth types, $27 \%$ (432 students) were in elementary, $43.6 \%$ (697 students) were in middle school, and 29.4\% (470 students) were in high school .

Second, if you look at the risk factors analysis results of the study, the average of "depression and anxiety" was the highest, followed by "aggression, impulsiveness and carelessness", "school life maladjustment", "community harm environment", "parent conflict and neglect", and "problem family members". Gender-specific results showed that the mean difference was statistically significant at all significance levels of 5\%, and women's mean was higher than men's in all factors except for the Flight Friend factor. By type of youth, aggression, impulsiveness, carelessness, conflict and neglect with parents, and problematic family members showed the highest average of elementary school students, middle school students in depression and anxiety, conflict between parents, harmful environment in the community, and delinquent friends. The average difference in aggression, impulsiveness, carelessness, conflict between parents, harmful environments in the community, and factors of delinquent friends was statistically significant at $5 \%$ of the significance level.

Third, if you look at the results of the study's analysis of protective factors, "friend relationships" were the highest, followed by "family interest and trust," "target awareness," "active response," "self-esteem," "teacher interest and relationship," and "support system." Gender-specific results showed that the average difference was statistically significant at $5 \%$ of the significance level, with the average of men higher than women in individuals, families, and communities, and the average of women higher than men in peers and schools. By type of youth, the average difference was statistically significant at $5 \%$ of the significance level in all factors except the community. In all areas, the average of high school students was the highest.

Fourth, the results of the analysis of crisis results were examined by gender and type of youth. As a result of the gender crisis, the average comparison was higher for women than men in the areas of suspension and school maladjustment, and for men in other areas, the average was higher for men than women. As a result of the crisis, the women's average was higher than the men's average, and the difference was statistically significant. As a result of the crisis caused by the type of youth, the average comparison of school violence (damage and abuse) was the highest among elementary school students. As a result of the crisis, the average of middle school students was the highest, and the average difference between youth types was statistically significant.

By investigating the risk factors of adolescents, the government sought to develop a program to improve resilience and prevent school violence. Research on improving resilience organized the contents of the resilience program by referring to self-control improvement[9], problem solving[11] through emotion control, and related prior research data. In the program process, the subjects planned to develop and develop their strengths to strengthen their inner emotions and help them realize themselves in a healthier way while more actively resolving conflicts and problems between people. There were a number of activities that were determined to have been properly implemented before the 
program was implemented, but could not be carried out within a fixed time. Therefore, for some activities, they were either deleted or restructured so that they could be done within the session. In addition, the motivation-inducing and introductory videos were changed to shorter and more implicit content, and the 'Cleaning Up Your Day' activity, which was organized every even time, was changed to check every day using smartphone messengers. Through this, it was intended to increase the efficiency of overall activities and secure sufficient time for activities.

In order to verify the continuous effectiveness of the resilience program, it is necessary to use measuring tools such as school adaptation, peer relations, and school satisfaction to conduct pre-harvest tests. According to these results, resilience and interpersonal skills can be maintained and improved. In particular, interpersonal skills in adolescents can experience positive school adaptation if they maintain a smooth relationship with their peers, and the level of school satisfaction increases while improving resilience.

Finally, as a result of this study, programs for the prevention of school violence should be developed to eliminate risk factors and strengthen protection factors. In particular, there is an implication that different types of risk factors should be approached when exploring protective factors that can further mitigate risk factors.

\section{References}

[1] H. K. Kim, The Effect of School-Related Factors on Youth Violence, Chung-Ang University, Master's Thesis, (1996)

[2] K. S. Kim, H. Y. Kim, Changes in the Characteristics of First-Year Students at the University of Education: Based on the Survey of Entering Freshmen in 2013 at Seoul National University of Education, Korean Journal of Elementary Education, (2013), Vol.24, No.3, pp.185-205, DOI : 10.20972/kjee.24.3.201309.185

[3] H. J. Kim, The Effect of Marital Conflict on Youth Peer Relationships: Focusing on Self-Opening Control Effects, Yonsei University, Master's Theis, (2005)

[4] A. M. La Greca, H. M. Harrison, Adolescent peer relations, friendships, and romantic relationships, Journal of Clinical Child and Adolescent Psychology, (2005), Vol.34, No.1, pp.49-61.

[5] M. S. Yoon, H. J. Cho, Effects of Violence Experience Type on Adolescent's Depression, Alcohol Use, Mental Health \& Social Work, (2008), Vol.29, $\quad$ No.8, https://www.dbpia.co.kr/Society/articleDetail/NODE06082112?pubId=11080\&selPid=\&isView=N

[6] J. S. Lee, The school adaptation process of victims of school violence approached with evidence theory, Myongji University, Doctoral Dissertation, (2012)

[7] E. J. Anthony, Risk, vulnerability, and resilience: An overview, The invulnerable child, USA New York: Guildford Press, (1987)

[8] N. S. Park, Resilience, Hakjisa, (2015), https://www.hakjisa.co.kr/subpage.html?page=book_book_info\&bidx=3222

[9] Kwi Hwa Park, Joo Hyun Park, Sun Kim, Jung Ae Rhee, Jong Hoon Kim, Young Joon Ahn, Jae Jin Han, Duk Joon Suh, Students' perception of the educational environment of medical schools in Korea: findings from a nationwide survey, Korean Journal of Medical Education, (2015), Vol.27, No.2, pp.117-130, doi: https://doi.org/10.3946/kjme.2015.27.2.117

[10] J. M. Park, The effect of group art therapy on improving resilience in middle school students who are poor at learning, Kyungnam University of Science and Technology, Master's Thesis, (2016)

[11] M. K. Lee, G. M. Lee, The Effects of Group Art Therapy program on the Ego-Resilience of the Low-Income Families' Youths, Korean Journal of Art Therapy, (2014), Vol.21, No.3, pp.499-517, DOI : 10.35594/kata.2014.21.3.007

[12] H. J. Kim, J. H. Lim, J. W. Jung, The Effect of Positive Psychology Group Art Therapy on Resilience of Middle Aged Women and their Coping Ability with Stress, Clinical Art Psychology Study, (2018), Vol.8, No.3, pp.71-100, DOI : 
10.34167/cliart.8.3.201812.71

[13] H. J. Lee, The Effects of Positive Psychology-Based Group Art Therapy on the Self Efficacy and Subjective Happiness of Art Therapy Major Students, Korean Journal of Art Therapy, (2020), Vol.27, No.3, pp.493-512, DOI : 10.35594/kata.2020.27.3.006

[14] S. Palomares, All about me: Reproducible activity sheets to develop self-esteem in your students, USA CA: Innerchoice Publishing, (1991), https:/www.innerchoicepublishing.com/book/all-about-me/

[15] S. H. Park, Effect of class self-esteem promotion program on self-esteem in elementary school students, Kyungpook National University, Master's Thesis, (2010)

[16] S. G. Hwang, J. H. Son, D. H. Kim, H. Y. Kim, Development Factor Analysis of the Youth Counseling and Welfare Center, The Korea Journal of Youth Counseling, (2016), Vol.24, No.1, pp. 197-219, DOI : 10.35151/kyci.2016.24.1.010 